\title{
EDITORIAL, v. 24, n. 1, JAN./ABR. 2020: O SILÊNCIO - OU APATIA - DA UNIVERSIDADE, A CRISE E A EROSÃO DA RAZÃO DEMOCRÁTICA
}

\author{
EDITORIAL, v. 24, n. 1, JAN./APR. 2020: LA SILENCIA - O APATÍA- DE LA \\ UNIVERSIDAD, LA CRISIS Y LA EROSION DE LA RAZON DEMOCRATICA \\ EDITORIAL, v. 24, n. 1, JAN./APR. 2020: THE SILENCE - OR APATHY - OF THE \\ UNIVERSITY, THE CRISIS AND THE EROSION OF DEMOCRATIC REASON
}

\author{
Sebastião de Souza LEMES ${ }^{1}$ \\ José Anderson SANTOS CRUZ ${ }^{2}$
}

A tradição política e cultural da sociedade brasileira parece ter se voltado para suas raízes mais perversas por meio dos movimentos civilizatórios que, de tempos em tempos, nos impõe uma nova que qualifica e melhora, em tese, nossas relações pessoais e sociais. É intrigante pensar sobre porque isso está acontecendo, pois, ao mesmo tempo que estamos envolvidos em uma "crise" conjuntural e, a meu ver, estrutural na sociedade em geral e, em particular, no Estado brasileiro que é onde as relações se encontram mais deterioradas do que nunca. Há também a “crise” política e a econômica, há a "crise” acadêmica, a “crise” social e, hoje, a "crise" do Covid-19 (Coronavirus), essa, ao que parece, não se esperava (será?). Nesse contexto, a palavra crise assume uma dimensão polissêmica de tal ordem que serve como argumento para quase tudo que acontece. Tendo em perspectiva o país, com sua diversidade e miscigenação cultural, social e étnica, o que vemos é a busca pela evidencia da diferença que desqualifica, pelo divisionismo entre grupos que empregam tom imperativo ao se manifestarem fazendo da natureza do contraditório no debate democrático um instrumento de agressão. O argumento é: a democracia no Brasil está em crise e a origem desta são os “inimigos" internos e, por isso, a capacidade de persuasão e a responsabilidade democrática se sustentam cada vez menos na argumentação pela razão, no debate em busca da compreensão pelo contraditório e da percepção clara dos problemas que submetem e afligem a população. Tendo como princípio a democracia há que se ter em perspectiva uma visão mais ampla da

\footnotetext{
${ }^{1}$ Universidade Estadual Paulista (Unesp), Faculdade de Ciências e Letras, Araraquara - SP - Brasil. Professor do Departamento de Antropologia, Política e Filosofia. Coordenador do Programa de pós-graduação em Educação Escolar. Editor. Orcid: https://orcid.org/0000-0002-0750-9294. E-mail: ss.lemes@gmail.com.

${ }^{2}$ Universidade Estadual Paulista (Unesp), Faculdade de Ciências e Letras, Araraquara - SP - Brasil. Doutorando no Programa de Pós-graduação em Educação Escolar. Bolsista CAPES/DS. Editor Adjunto e Executivo. Assessoria Técnica para periódicos da Educação. Orcid: http://orcid.org/0000-0001-5223-8078. E-mail: andersoncruz.unesp@gmail.com.
} 
complexidade que envolve a sociedade brasileira e, por isso, favorecer o amplo debate a partir de diferentes percepções e ideias sobre a realidade construída e não na manipulação do inconsciente nos diferentes grupos sociais. O descritivo qualificado que evidencia esse modo de pensar encontra-se no texto de Brittany Kaiser, no seu livro, apropriadamente intitulado "Manipulados", onde a autora mostra como a empresa Cambridge Analytica e o Facebook invadiram a privacidade de milhões de pessoas e redirecionaram tendências políticas efetivamente consolidadas, colocando a democracia diante de grandes dificuldades, a ponto de ter seus fundamentos questionados e, até certo ponto, desafiados. Nesse propósito, apesar de não tão evidente em princípio, mostra, por meio das diferentes faces da persuasão a manipulação dos desejos (e/ou necessidades) mais insólitos, nas dimensões mais profundas do inconsciente humano, como conduzir o indivíduo para onde se pretende. Essa democracia de "mercado" não precisa da lógica do argumento para persuadir, precisa explorar a ilógica e inconsistente fragilidade das pessoas pela desinformação em um contexto onde o "mercado" é determinado (dominado) pela conveniência das corporações que, com as pressões que exercem sobre o conjunto dos sistemas políticos, desestruturam a democracia produzindo conflitos entre a regulação produzida por decisões tomadas politicamente por cidadãos legitimamente empoderados por toda sociedade e as necessidades do atendimento à ganancia predatória de um poder econômico a quem o estado, enquanto Nação, nada ou pouco significa. A legitimidade política se fragiliza, o exercício do poder político é transferido para o poder econômico e a ele se submete. Este, por sua vez, não presta contas à sociedade, mas aos investidores e, aqui, é onde se ampliam as diferenças e se estabelecem marcos divisionistas na sociedade. Essa submissão faz com que a democracia seja constantemente desorganizada por políticas e políticos empoderados com traços autoritários agindo em nome do poder econômico. É desafiada pela rapidez como que as informações (verdadeiras ou falsas) são disseminadas no estado de direito e o poder jurídico lento, burocrático, idiossincrático e, geralmente, também submisso a esse mesmo poder econômico ou corporativo, definem o que é a verdade e o que não é, porém não consegue agir com presteza suficiente para conter a desinformação estabelecida na sociedade. Nesse contexto e sentido, as novas técnicas de comunicação virtualizadas e dinamizadas por meio das redes sociais disseminado as "fake news" também subvertem o estado de direto, modificam o debate democrático e alteram o ritmo político na dinâmica das decisões a que todos afetam. Estabelecem uma forma de comunicação que constrói e orienta a realidade a seu favor (melhor relembrar o papel da Cambridge Analytica). 
Após esse contexto descrito fica a pergunta; onde está a universidade? Não há, pelo menos de forma aparente, uma única resposta plausível para essa pergunta, porem podemos refletir sobre esse silêncio (ou apatia) dessa instituição que, por sua natureza, é quem pode e deve, criticamente, assumir seu papel e função na sociedade e se apresentar ao esclarecimento que qualifica e critica o debate político em favor de toda sociedade, se não, qual seu valor e seu sentido para a sociedade que hoje se encontra submetida à essa situação? A Universidade não pode ser mais uma instituição submetida a essa situação e a serviço de uma democracia de (e para) consumo (de mercado). 